\title{
PENGARUH PUPUK P DAN VARIETAS TERHADAPPERTUMBUHAN, PRODUKSI, DAN MUTU BENIH KEDELAI (Glycine max [L.] Merrill) YANG DITANAM Di MUSIM PENGHUJAN
}

\author{
Agustiansyah $^{1)}$,Alvika Putri' ${ }^{2)}$, Ermawati ${ }^{3)}$, Niar Nurmauli ${ }^{3)}$ \\ ${ }^{1}$ Dosen Jurusan Agronomi dan Hortikultura Fakultas Pertanian Universitas Lampung \\ ${ }^{2}$ Mahasiswa Jurusan Agroteknologi Fakultas Pertanian Universitas Lampung \\ ${ }^{3}$ Dosen Jurusan Agroteknologi Fakultas Pertannian Universitas Lampung \\ Jln. Prof. Dr. Soemantri Brojonegoro No. 1 Bandar Lampung 35145
}

\begin{abstract}
ABSTRAK
Peningkatan produktivitas kedelai dapat diupayakan melalui penggunaan varietas unggul, pemupukan yang optimum, dan penanaman yang tepat musim. Tujuan penelitian ini adalah: (1) Mengetahui varietas kedelai yang dapat menghasilkan pertumbuhan, produksi, dan mutu benih terbaik dari ketiga varietas yang digunakan; (2) Mengetahui dosis pupuk fosfat yang optimum dalam meningkatkan pertumbuhan, produksi, dan mutu benih kedelai pada varietas yang digunakan; (3) Mengetahui interaksi antara pemberian pupuk fosfat dan varietas kedelai dalam mempengaruhi pertumbuhan, produksi, dan mutu benih. Penelitian ini dilaksanakan di Desa Karang Anyar, Kecamatan Gedong Tataan, Kabupaten Pesawaran, Provinsi Lampung kemudian dilanjutkan di Laboratorium Benih dan Pemuliaan Tanaman Universitas Lampung. Penelitian dilaksanakan pada Oktober 2017 sampai Februari 2018. Penelitian ini menggunakan rancangan perlakuan faktorial (3 x 5) dalam Rancangan Kelompok Teracak Sempurna (RKTS) dan setiap perlakuan dilakukan sebanyak tiga kali ulangan. Faktor pertama adalah tiga varietas, yaitu Anjasmoro $\left(\mathrm{V}_{1}\right)$, Grobogan $\left(\mathrm{V}_{2}\right)$, dan Burangrang $\left(\mathrm{V}_{3}\right)$. Faktor kedua adalah dosis SP-36 yaitu $0\left(\mathrm{P}_{0}\right), 100\left(\mathrm{P}_{1}\right), 150\left(\mathrm{P}_{2}\right), 200\left(\mathrm{P}_{3}\right)$, dan $250 \mathrm{~kg} /$ hektar $\left(\mathrm{P}_{4}\right)$.Homogenitas ragam antarperlakuan diuji dengan Uji Bartlett dan non aditivitas data diuji dengan Uji Tukey. Asumsi anara terpenuhi maka data dianalisis ragam dan dilanjutkan dengan uji perbandingan ortogonal. Semua pengujian dilakukan pada tarafá 5\%. Pertumbuhan dan produksi varietas berumur sedang (Anjasmoro dan Burangrang) lebih tinggi daripada varietas berumur genjah (Grobogan). Mutu benih varietas berumur genjah lebih baik daripada varietas berumur sedang.Pemberian pupuk fosfat sampai $250 \mathrm{~kg} /$ ha belum mampu mendapatkan dosis optimum untuk ketiga varietas kedelai hanya terdapat dosis pemupukan fosfat yang baik. Pemberian pupuk fosfat dengan dosis SP-36 $150 \mathrm{~kg} / \mathrm{hektar}$ menunjukkan pertumbuhan dan produksi varietas berumur sedang lebih tinggi daripada varietas berumur genjah, sedangkan pemupukan SP-36 dosis 100, 150, 200, dan $250 \mathrm{~kg}$ /hektar menunjukkan mutu varietas genjah lebih baik daripada varietas berumur sedang.
\end{abstract}

Kata kunci: Kedelai, mutu benih, musim penghujan, pertumbuhan, produksi

\section{PENDAHULUAN}

Kedelai (Glycine max [L.] Merril.) merupakan komoditas pertanian yang sangat dibutuhkan di Indonesia, baik sebagai bahan pangan dan pakan ternak. Konsumsi bahan pangan yang berasal dari kedelai terus meningkat setiap tahunnya. Upaya peningkatan kuantitas dan kualitas produktivitas kedelai di Indonesia merupakan tantangan serius untuk mempertahankan kelangsungan pengembangan produktivitas agar dapat memenuhi kebutuhan kedelai 
di Indonesia.

Di Indonesia, menurut Rukmana dan Yudirachman (2014), sasaran produktivitas kedelai nasional yang ingin dicapai adalah rata-rata 1,5 ton/ hektar, maka kebutuhan areal tanam kedelai diperkirakan menjadi seluas 2,24 juta hektar pada tahun 2025. Produktivitas kedelai saat ini mencapai 1,2 ton/hektar sedangkan produksi rerata dunia sudah mencapai 1,9 ton/hektar. Strategi peningkatan produksi kedelai nasional dilakukan melalui program perluasan areal tanam atau panen. Pemanfaatan lahan kering sebagai upaya memperluas areal tanam kedelai mulai banyak diterapkan.

Pemilihan varietas juga penting dilakukan untuk menunjang produktivitas kedelai yang diproduksi di lahan kering. Upaya yang dilakukan adalah dengan menggunakan varietas unggul yang diminati petani dan dapat beradaptasi dengan lingkungan. Menurut Krisdiana (2013), varietas kedelai yang termasuk dalam varietas berukuran biji besar yang diminati petani, karena untuk pemenuhan kebutuhan industri tempe. Berdasarkan Rukmana et al. (2014) bahwa varietas unggul memiliki kriteria potensi hasil yang tinggi, berumur pendek (genjah), tahan terhadap hama dan penyakit, serta unggul dari segi lainnya.

Pupuk fosfat merupakan salah satu pupuk yang mempunyai peranan penting untuk tanaman kedelai, dapat merangsang perkembangan akar sehingga tanaman akan lebih tahan terhadap kekeringan mempercepat pembungaan dan pemasakan buah, biji atau gabah selain itu juga dapat menambah nilai gizi (lemak dan protein) dari biji (Sihaloho et al., 2015).
Berdasarkan penelitian Thoyibbah et al. (2014) pemberian pupuk fosfat berpengaruh nyata terhadap tinggi tanaman, jumlah biji per tanaman, bobot 100 butir, bobot biji per tanaman, dan indeks panen.

Peranan fosfat yang penting dalam mencapai kuntitas dan kualitas benih yang maksimal menjadikan perlu adanya pemupukan fosfat dengan dosis yang tepat. Pada penelitian Kurniawan et al. (2014) bahwa Varietas Grobogan produksi biji terbaik didapatkan dengan pemberian pupuk $50 \mathrm{~kg} \mathrm{P}_{2} \mathrm{O}_{5} /$ hektar hasilnya yaitu 1,65 ton/hektar, sedangkan Varietas Anjasmoro dan Burangrang produksi terbaik dihasilkan yaitu yang tidak diberi pupuk $\mathrm{P}$ yaitu hasilnya 1,93 ton/hektar dan 1,2 ton/hektar. Hasil penelitian tersebut menunjukkan bahwa produksi terbaik dapat berbeda tergantung taraf dosis pupuk fosfat yang diberikan dan respon varietas. Pemupukan fosfat dengan dosis yang tepat diharapkan akan menghasilkan pertumbuhan, produksi, dan mutu benih kedelai yang baik. Perlu adanya informasi mengenai keterkaitan interaksi antara dosis pupuk fosfat yang diberikan dan varietas kedelai unggul yang digunakan.

Tujuan penelitian ini adalah: 1) Mengetahui varietas kedelai yang dapat menghasilkan pertumbuhan, produksi, dan mutu benih yang baik dari ketiga varietas yang digunakan; 2) Mengetahui dosis pupuk fosfat yang optimum dalam meningkatkan pertumbuhan, produksi, dan mutu benih kedelai pada varietas yang digunakan; 3) Mengetahui interaksi antara pemberian pupuk fosfat dan varietas kedelai dalam mempengaruhi pertumbuhan, produksi, dan mutu benih. 


\section{METODE PENELITIAN}

\section{Waktu dan Tempat Penelitian}

Penelitian dilaksanakan di lahan kering yang terletak di Desa Karang Anyar, Kecamatan Gedong Tataan, Kabupaten Pesawaran dilanjutkan di Laboratorium Benih dan Pemuliaan Tanaman Fakultas Pertanian Univesitas Lampung. Waktu penelitian adalah saat musim hujan dari Oktober 2017 sampai dengan Februari 2018.

\section{Bahan dan Alat}

Bahan-bahan yang digunakan adalah benih kedelai Varietas Anjasmoro, Varietas Grobogan, dan Varietas Burangrang, Rhizoka, Urea, KCL, SP-36, insektisida, herbisida, dan fungisida.Alat-alat yang digunakan adalah knapsack sprayer, gunting, timbangan analitik, dan oven.

\section{Metode Penelitian}

Rancangan perlakuan disusun secara faktorial (3x5) dan setiap perlakuan dilakukan sebanyak tiga kali ulangan. Faktor pertama adalah tiga varietas, yaitu Anjasmoro $\left(\mathrm{V}_{1}\right)$, Grobogan $\left(\mathrm{V}_{2}\right)$, dan Burangrang $\left(\mathrm{V}_{3}\right)$. Faktor kedua adalah dosis SP-36 yaitu $0\left(\mathrm{P}_{0}\right)$, $100\left(\mathrm{P}_{1}\right), 150\left(\mathrm{P}_{2}\right), 200\left(\mathrm{P}_{3}\right)$, dan $250 \mathrm{~kg} /$ hektar $\left(\mathrm{P}_{4}\right)$.

Kombinasi perlakuan diterapkan dalam satuan percobaan berupa lahan kering dalam rancangan kelompok teracak sempurna (RKTS ). Satu satuan petak percobaan berukuran $4 \mathrm{~m}$ x $3 \mathrm{~m}$, dan setiap kelompok terdiri dari 15 petak percobaan. Pengelompokan berdasarkan waktu tanam yaitu selang satu minggu setelah tanam. Homogenitas ragam antarperlakuan diuji dengan Uji Bartlett dan non aditivitas data diuji dengan Uji Tukey. Asumsi anara terpenuhi data dianalisis ragam dan dilanjutkan dengan uji perbandingan ortogonal. Semua pengujian dilakukan pada taraf á $5 \%$.

\section{HASIL DAN PEMBAHASAN}

\section{Hasil Penelitian}

\section{Pertumbuhan kedelai}

Pengamatan kompenen pertumbuhan tanaman kedelai meliputi tinggi tanaman, jumlah buku, jumlah daun, luas area daun, dan bobot kering berangkasan. Hasil penelitian menunjukkan bahwa terdapat interaksi antara pupuk SP-36 dan varietas kedelai yang digunakan terhadap pertumbuhan kedelai yang ditunjukkan oleh variabel jumlah daun dan bobot kering berangkasan. Pemberian dosis SP-36 menghasilkan jumlah daun dan bobot kering berangkasan tergantung pada berbagai varietas (Tabel 1).

Pemberian dosis SP-36 menghasilkan tinggi tanaman dan jumlah buku tidak tergantung pada berbagai varietas. Tinggi tanaman dan jumlah buku Varietas Anjasmoro dan Varietas Burangrang tidak berbeda. Pemberian dosis SP-36 menghasilkan luas area daun tidak tergantung pada berbagai varietas. Pemberian SP-36 menghasilkan tinggi tanaman, luas area daun, dan jumlah buku tidak berbeda daripada tanpa SP-36. Pemberian dosis SP-36 mampu meningkatkan bobot kering berangkasan Varietas Grobogan secara linier. Setiap pemberian 1 kg SP-36 mampu meningkatkan bobot kering berangkasan Varietas Grobogan sebanyak 1,238 gram. 
Tabel 1. Rekapitulasi pengaruh dosis pupuk fosfatterhadap variabel jumlah daun trifoliat (JDT), bobot kering berangkasan (BKB), jumlah biji (JB), dan kecepatan perkecambahan (KP).

\begin{tabular}{|c|c|c|c|c|c|c|c|c|c|}
\hline \multirow{2}{*}{\multicolumn{2}{|c|}{ perbandingan }} & \multicolumn{2}{|c|}{ JDT } & \multicolumn{2}{|c|}{ BKB } & \multicolumn{2}{|c|}{ J B } & \multicolumn{2}{|c|}{$\mathbf{K P}$} \\
\hline & & F-hit & Selisih\% & F-hit & Selisih & F-hit & Selisih \% & F-h it & $\begin{array}{l}\text { Selisih } \\
\%\end{array}$ \\
\hline \multicolumn{10}{|c|}{ Varietas (A) } \\
\hline P1： & V2 Vs V1, V3 & $* *$ & 12,17 & $* *$ & 27,23 & $* *$ & 21,26 & $* *$ & 1,89 \\
\hline P2 : & $\mathrm{V} 1 \mathrm{Vs} \mathrm{V} 3$ & tn & 0,87 & $*$ & 4,83 & $\operatorname{tn}$ & 1,91 & $* *$ & 0,13 \\
\hline \multicolumn{10}{|c|}{ SP-36(B) } \\
\hline P3 : & P0 Vs P & $*$ & 9,63 & $\operatorname{tn}$ & $-0,24$ & tn & 1,13 & $* *$ & 0,29 \\
\hline P4: & P-Linier & tn & & $*$ & & $\operatorname{tn}$ & & $* *$ & \\
\hline P5 : & $\begin{array}{l}\text { P-Kuadratik } \\
\text { AXB }\end{array}$ & tn & & tn & & tn & & $* *$ & \\
\hline P6 : & P1 X P3 & tn & & tn & & $\operatorname{tn}$ & & $* *$ & \\
\hline P7 : & P1 X P4 & tn & & tn & & tn & & $* *$ & \\
\hline P8: & P1 XP5 & tn & & tn & & tn & & $* *$ & \\
\hline P9: & P2 X P 3 & $*$ & & $*$ & & $* *$ & & $* *$ & \\
\hline P 10: & $\mathrm{P} 2 \times \mathrm{P} 4$ & tn & & tn & & $* *$ & & $* *$ & \\
\hline \multirow[t]{2}{*}{ P11: } & P2 X P 5 & tn & & tn & & tn & & $* *$ & \\
\hline & Tanggapan tan & elai terha & arietas pada & & & & & & \\
\hline \multirow[t]{2}{*}{ P0 : } & V2 Vs V1, V3 & tn & 9,52 & $* *$ & 25,98 & $* *$ & 22,92 & $* *$ & 2,50 \\
\hline & $\mathrm{V} 1 \mathrm{Vs} \mathrm{V} 3$ & tn & 21,05 & $* *$ & 14,02 & $* *$ & 14,05 & $* *$ & 0,37 \\
\hline \multirow[t]{2}{*}{ P 100: } & $\mathrm{V} 2 \mathrm{Vs} \mathrm{V} 1, \mathrm{~V} 3$ & tn & 9,68 & $* *$ & 28,65 & $* *$ & 27,97 & $* *$ & 0,93 \\
\hline & V1 Vs V3 & tn & 2,17 & tn & 6,15 & tn & 9,12 & $* *$ & 0,74 \\
\hline \multirow[t]{2}{*}{ P 150 : } & $\mathrm{V} 2 \mathrm{Vs} \mathrm{V} 1, \mathrm{~V} 3$ & ** & 22,58 & $* *$ & 29,69 & $* *$ & 19,68 & $* *$ & 2,04 \\
\hline & V1 Vs V3 & tn & 6,25 & tn & 5,63 & tn & 4,07 & $* *$ & 0,74 \\
\hline \multirow[t]{2}{*}{ P200 : } & V2 Vs V1, V3 & tn & 11,83 & $* *$ & 29,85 & $* *$ & 17,33 & $* *$ & 2,24 \\
\hline & V1 Vs V3 & tn & 10,20 & $\operatorname{tn}$ & $-0,38$ & tn & 8,39 & $* *$ & 0,74 \\
\hline \multirow[t]{3}{*}{ P250 : } & V2 Vs V1, V3 & tn & 7,22 & $* *$ & 22,09 & $* *$ & 18,31 & $* *$ & 1,73 \\
\hline & V1 Vs V3 & tn & 2,08 & tn & $-0,47$ & tn & 7,41 & $* *$ & 0,26 \\
\hline & Tanggapan tan & elai terha & sis SP-36 & & & & & & \\
\hline \multirow[t]{3}{*}{ V1: } & P0 Vs P & tn & & tn & & tn & & $*$ & \\
\hline & P-Linier & tn & & tn & & tn & & $\mathrm{tn}$ & \\
\hline & P-Kuadratik & tn & & tn & & tn & & $\mathrm{tn}$ & \\
\hline \multirow[t]{3}{*}{ V2: } & P0 Vs P & tn & & tn & & tn & & tn & \\
\hline & P-Linier & tn & & $*$ & & tn & & tn & \\
\hline & P-Kuadratik & tn & & tn & & tn & & tn & \\
\hline \multirow[t]{3}{*}{ V3: } & P0 Vs P & ** & & tn & & tn & & tn & \\
\hline & P-Linier & tn & & tn & & tn & & tn & \\
\hline & P-Kuadratik & tn & & tn & & $\operatorname{tn}$ & & $\mathrm{tn}$ & \\
\hline
\end{tabular}

Keterangan: $\mathrm{tn}=$ tidak berbeda pada á $5 \%, \mathrm{~V} 1=$ Anjasmoro, $\mathrm{P} 0=0 \mathrm{~kg} / \mathrm{ha} \mathrm{SP}-26, \mathrm{P} 100=100 \mathrm{~kg} / \mathrm{ha} \mathrm{SP}-36$

$*=$ berbeda pada á $5 \%, \mathrm{~V} 2=$ Grobogan, P150 $=150 \mathrm{~kg} / \mathrm{ha} S \mathrm{SP}-26, \mathrm{P} 200=200 \mathrm{~kg} / \mathrm{ha} \mathrm{SP}-36$

$* *=$ berbeda pada á $5 \%, \mathrm{~V} 3=$ Grobogan, $\mathrm{P} 250=250 \mathrm{~kg} / \mathrm{ha} \mathrm{SP}-26$,

\section{Produksi kedelai}

Pengamatan kompenen produksi tanaman kedelai meliputi jumlah polong total, jumlah biji per tanaman, bobot biji per tanaman, dan laju pengisian biji. Hasil penelitian menunjukkan bahwa terdapat interaksi antara pupuk SP-36 dan varietas kedelai yang digunakan terhadap produksi kedelai yang ditunjukkan variabel jumlah biji per tanaman. Pemberian dosis SP36 menghasilkan jumlah biji pertanaman tergantung pada berbagai varietas (Tabel 2). Jumlah biji pertanaman yang dihasilkan pada $\mathrm{P}_{0} ; \mathrm{P}_{100} ; \mathrm{P}_{150} ; \mathrm{P}_{200} ; \mathrm{P}_{250}$ Varietas Anjasmoro dan Burangrang lebih banyak daripada Varietas Grobogan (Tabel 1).

Pemberian dosis SP-36 menghasilkan jumlah 
polong total, bobot biji, dan laju pengisian biji tidak tergantung pada berbagai varietas. Pemberian SP-36 menghasilkan jumlah polong total, bobot biji, dan laju pengisian biji tidak berbeda dibandingkan dengan tanpa SP-36. Pemberian dosis SP-36 menghasilkan jumlah polong total, bobot biji, dan laju pengisian biji relatif sama. Pemberian dosis SP-36 sampai pada $250 \mathrm{~kg} /$ ha meningkatkan laju pengisian biji kedelai secara linier. Setiap pemberian $1 \mathrm{~kg}$ SP-36 mampu meningkatkan laju pengisian biji kedelai 0,047 g/hari.

\section{Mutu benih}

Pengamatan kompenen mutu benih kedelai meliputi daya berkecambah, kecepatan perkecambahan, dan bobot 1.000 butir. Hasil penelitian menunjukkan bahwa terdapat interaksi antara pupuk SP-36 dan varietas kedelai yang digunakan terhadap mutu benih kedelai yang ditunjukkan oleh variabel kecepatan perkecambahan. Pemberian dosis SP-36 menghasilkan kecepatan perkecambahan tergantung pada berbagai varietas. Kecepatan perkecambahan pada $\mathrm{P}_{0} ; \mathrm{P}_{100} ; \mathrm{P}_{150} ; \mathrm{P}_{200} ; \mathrm{P}_{250}$ persentase kecepatan perkecambahan Varietas Anjasmoro dan Burangrang lebih rendah daripada Varietas Grobogan (Tabel 1).

Pemberian dosis SP-36 menghasilkan daya berkecambah dan bobot 1.000 butir tidak tergantung pada berbagai varietas. Pemberian SP-36 menghasilkan daya berkecambah dan bobot 1.000 butir tidak berbeda dibandingkan dengan tanpa SP36. Pemberian dosis SP-36 menghasilkan daya berkecambah dan bobot 1.000 butir relatif sama.

\section{Pembahasan}

Hasil penelitian menunjukkan terdapat interaksi antara pupuk fosfat dengan varietas yang digunakan. Pemberian dosis pupuk SP-36 bergantung pada varietas dalam mempengaruhi pertumbuhan, produksi, dan mutu benih. Varietas berumur sedang (Anjasmoro dan Burangrang) memiliki hasil pertumbuhan dan produksi lebih baik daripada varietas berumur genjah (Grobogan) pada dosis SP-36 150 kg/hektar. Hal ini ditunjukkan dari hasil jumlah daun, bobot kering berangkasan ,dan jumlah biji pertanaman varietas berumur sedang yang lebih tinggi daripada varietas berumur genjah pada dosis SP-36 $150 \mathrm{~kg} /$ hektar. Pada pemupukan $150 \mathrm{~kg} /$ hektar SP-36 varietas berumur sedang memiliki hasil terbaik dengan jumlah daun varietas berumur sedang memiliki selisih $22,58 \%$ lebih banyak daripada varietas berumur genjah dan bobot kering berangkasan memiliki hasil terbaik dengan selisih $72,84 \%$ lebih berat daripada varietas berumur genjah. Varietas berumur sedang yang memiliki jumlah daun lebih banyak mampu mendukung hasil bobot kering berangkasan lebih tinggi. Sesuai dengan pendapat Siregar et al. (2017) bahwa tanaman kedelai yang tinggi dan jumlah daunnya banyak maka jumlah fotosintat yang ditransfer ke buah atau biji akan semakin besar. Hasil fotosintat tersebut akan ditranslokasikan di dalam tanaman sehingga bobot kering berangkasan tanaman juga meningkat.

Pertumbuhan yang baik mendukung hasil produksi yang baik pada varietas berumur sedang untuk jumlah biji per tanaman. Sesuai dengan pendapat Rahajeng dan Muclish ( 2013) dalam menunjang 
produktivitas kedelai berumur sedang memiliki jumlah polong dan biji lebih banyak dibandingkan dengan kedelai berumur genjah yang lebih singkat menyelesaikan masa produksinya. Pemberian pupuk fosfat juga memiliki pengaruh yang nyata pada hasil jumlah biji per tanaman. Jumlah biji per tanaman yang dihasilkan varietas berumur sedang lebih banyak disemua taraf dosis pemupukan yang diberikan daripada varietas berumur genjah, pada dosis SP-36 $150 \mathrm{~kg} /$ hektar jumlah biji per tanaman varietas berumur sedang memiliki selisih cukup tinggi hingga 35,70\% lebih banyak daripada varietas berumur genjah. Hal ini sesuai dengan penelitian Thoyibbah et al. (2014) bahwa pemberian pupuk fosfat berpengaruh nyata teradap tinggi tanaman, jumlah biji per tanaman, bobot 100 butir, bobot biji per tanaman, dan indeks panen.

Varietas berumur sedang didukung sifat genetik varietas memiliki hasil pertumbuhan dan produksi lebih tinggi daripada varietas berumur genjah pada tinggi tanaman, jumlah buku, jumlah polong total, dan bobot biji per tanaman. Varietas Burangrang dan Varietas Anjasmoro memiliki tinggi tanaman berkisar $66,97 \mathrm{~cm}$ lebih tinggi 17,17\% dibandingkan dengan Varietas Grobogan yang memiliki tinggi tanaman rata-rata 55,47 cm. Varietas Burangrang dan Varietas Anjasmoro memiliki jumlah buku 12,67 buku lebih banyak 13,68\% dibandingkan dengan Varietas Grobogan yang memiliki jumlah buku rata-rata 10,93 buku. Varietas Burangrang dan Varietas Anjasmoro memiliki rata-rata jumlah polong total 51,40 polong lebih banyak 38,59\% dibandingkan dengan Varietas Grobogan yang memiliki jumlah polong total rata-rata 31,57 polong. Varietas
Burangrang dan Varietas Anjasmoro memiliki rata-rata bobot biji per tanaman 19,59 gram lebih berat 15,91\% dibandingkan dengan Varietas Grobogan yang memiliki bobot biji per tanaman rata-rata 16,47 gram.

Varietas berumur genjah lebih baik daripada varietas berumur sedang pada dosis 100, 150, 200, dan 250 SP-36 kg/hektar dalam meningkatkan mutu benih. Hal ini ditunjukkan oleh kecepatan perkecambahan varietas berumur genjah lebih baik dibandingkan dengan varietas berumur sedang pada dosis SP-36 100, 150, 200, dan $250 \mathrm{~kg} /$ hektar. Varietas Grobogan memiliki mutu yang lebih baik diduga didukung dari faktor genetik yaitu ukuran benih dan juga didukung dari pengaruh nyata pemberian pupuk P. Berdasarkan hasil penelitian Perdana et al. (2012 ) pemberian pupuk P meningkatkan daya kecambah pada benih yang dipanen pada berbagai tingkat perkembangan biji yang menandakan bahwa pupuk P mempercepat proses pemasakan biji pada berbagai varietas kedelai. Pada benih, P disimpan sebagai fitin, yang terdiri dari garam kalsium dan magnesium dari asam fitat. Fitin akan digunakan sebagai sumber energi utama bagi benih selama proses perkecambahan (Tisdale et al., 1985 dalam Rahmawati 2018). Mengel \& Kirby (1982) dalam Syarief(2005) menyatakan bahwa benih tanaman yang dihasilkan dari tanaman yang mendapat cukup P akan memiliki viabilitas dan vigor yang tinggi karena pada benih yang cukup P kandungan senyawa fitin akan lebih tinggi. Hal inilah yang mendukung Varietas Grobogan mampu memiliki mutu benih lebih baik dibandingkan kedua varietas lainnya, karena selain dipengaruhi dari pupuk 
fosfat yang diberikan ukuran benih juga mempengaruhi mutu benih kedelai. Hasil penelitian menunjukkan bobot 1.000 rata-rata varietas berumur sedang adalah $155,094 \mathrm{~g}$, sedangkan rata-rata bobot 1.000 butir varietas berumur genjah adalah 212,4 g. Berdasarkan Yulyatin danDiratmaja ( 2015) bahwa benih ukuran besar umumnya lebih vigor dibandingkan ukuran benih sedang dan kecil, hal ini disebabkan cadangan makanan benih ukuran besar lebih banyak dibandingkan dengan benih ukuran kecil. Pengaruh pupuk P pada mutu benih juga terlihat pada Varietas Anjasmoro yang menunjukkan kecepatan perkecambahan yang diberi pupuk fosfat akan memiliki hasil persentase lebih tinggi dibandingkan tanpa diberi pupuk fosfat.

Pada bobot 1.000 butir varietas berumur genjah memiliki hasil lebih bobot lebih berat daripada varietas berumur sedang. Pada bobot 1.000 butir antara varietas berumur sedang menunjukkan hasil Varietas Burangrang memiliki bobot lebih berat daripada Varietas Anjasmoro. Bobot 1.000 butir rata-rata Varietas Grobogan adalah 212,40 gram lebih berat $36,95 \%$ dibandingkan dengan bobot 1.000 butir ratarata Varietas Anjasmoro dan Burangrang 155,09 gram. Hasil daya berkecambah menunjukkan varietas berumur genjah memiliki daya berkecambah lebih tinggi daripada varietas berumur sedang, sedangkan antara varietas berumur sedang daya berkecambah menunjukkan hasil relatif sama. Varietas Burangrang dan Varietas Anjasmoro memiliki rata-rata daya berkecambah 97,44\% lebih rendah 0,57\% dibandingkan dengan Varietas Grobogan yang memiliki daya berkecambah rata-rata 98,00\%. Hasil daya berkecambah dipengaruhi oleh sifat genetik varietas itu sendiri yaitu ukuran benih.

Pengaruh nyata pemberian pupuk fosfat mampu meningkatkan laju pengisian biji kedelai daripada tanpa pemupukan fosfat. Varietas berumur sedang (Anjasmoro dan Burangrang) memiliki hasil pertumbuhan dan produksi lebih baik daripada varietas berumur genjah (Grobogan) pada dosis SP-36 150 $\mathrm{kg} /$ hektar. Varietas berumur genjah lebih baik daripada varietas berumur sedang pada dosis 100, 150, 200, dan 250 SP-36 kg/hektar dalam meningkatkan mutu benih. Pemberian pupuk fosfat sampai $250 \mathrm{~kg} / \mathrm{ha}$ belum mampu mendapatkan dosis optimum untuk ketiga varietas kedelai hanya terdapat dosis pemupukan fosfat yang baik.

\section{KESIMPULAN DAN SARAN}

Berdasarkan penelitian yang telah dilakukan, maka diperoleh kesimpulan sebagai berikut :

1) Pertumbuhan dan produksi varietas Anjasmoro dan Burangrang lebih tinggi daripada varietas berumur genjah (Grobogan) pada tinggi tanaman sebanyak $17,17 \%$, jumlah buku 13,68\%, jumlah polong total 38,59\%, dan bobot biji per tanaman 15,91\%. Mutu benih varietas berumur genjah lebih tinggi daripada varietas berumur sedang pada daya berkecambah dengan selisih $0,57 \%$ dan bobot 1.000 butir $36,95 \%$; 2) Pemberian pupuk fosfat sampai $250 \mathrm{~kg} / \mathrm{ha}$ belum mampu mendapatkan dosis optimum untuk ketiga varietas kedelai hanya terdapat dosis pemupukan fosfat yang baik. 
Pemberian pupuk fosfat dengan dosis SP-36 $150 \mathrm{~kg} /$ hektar menunjukkan pertumbuhan dan produksi varietas berumur sedang lebih tinggi daripada varietas berumur genjah, sedangkan pemupukan SP-36 dosis 100, 150, 200, dan $250 \mathrm{~kg} /$ hektar menunjukkan mutu varietas genjah lebih baik daripada varietas berumur sedang.

\section{DAFTAR PUSTAKA}

Krisdiana, R. 2013. Dominasi Varietas Unggul Kedelai di Nangroe Aceh Darussalam: Kajian Penyebaran Varietas dan Prefensi Petani. Prosiding Seminar Hasil Penelitian Tanaman Aneka Kacang dan Umbi. Hlm. 293-299.

Kurniawan, S., R. Aslim, dan Wardati. 2014. Pengaruh Pemberian Pupuk Posfor terhadap Pertumbuhan Beberapa Varietas Kedelai (Glycine $\max$ L. Merril). Jom Faperta. $1(2): 1-11$.

Perdana, J.L., A. Rasyad, dan E. Zuhry. 2012. Pengaruh Beberapa Dosis Pupuk Fosfor (P) terhadap Mutu Benih Berbagai Kultivar Kedelai (Glycine max L. Merril ) Selama Pengisian dan Pemasakan Biji. Fakultas pertanian Universitas Riau. Pekanbaru. $12 \mathrm{hlm}$.

Rahajeng, W. dan A.M. Muclish. 2013. Varietas Kedelai Genjah. Buletin Palawija. 26: 91100.

Rahmawati, R. 2018. Pengaruh Fosfor dan Nitrogen pada Bobot Serat Mutu Benih Tanaman Kedelai Glycine max (L.) Merril). (Skripsi). Fakultas Pertanian Universitas Lampung. Bandar Lampung. 41hlm.
Rukmana ,R. dan H. Yudirachman. 2014. Budidaya dan Pengolahan Hasil Kacang Kedelai Unggul. CV Nuansa Aulia. Bandung. 202 hlm.

Sihaloho,N.S., N. Rahmawati, dan L.A.P. Putri. 2015. Respon Pertumbuhan dan Produksi Tanaman Kedelai Varietas Detam 1 terhadap Pemberian Vermikompos dan Pupuk P. Jurnal Agroteknologi Fakultas Pertanian Universitas Sumatera Utara. 3(4): 1591$1600 \mathrm{hlm}$.

Siregar, D. A., R.R. Lahay, dan N. Rahmawati. 2017. Respons Pertumbuhan danProduksi Kedelai (Glycine max L. Merril ) terhadap Pemberian Biochar Sekam Padi dan Pupuk P. Jurnal Agroteknologi Fakultas Pertanian Universitas Sumatera Utara. 5 (3): 722728.

SyarifAA. 2005. Adaptasi dan ketenggangan genotipe padi terhadap defisiensi fosfor di tanah sawah [Disertasi]. Sekolah Pascasarjana, Institut Pertanian Bogor.

Thoyyibah, S., Sumadi, dan A. Nuraini. 2014. Pengaruh Dosis Pupuk Fosfat Terhadap Pertumbuhan, Komponen Hasil, Hasil dan Kualitas Benih Dua Varietas Kedelai (Glycine $\max ($ L.) Merr.) Pada Inceptol Jatinangor. Journal of Agriculture Science. 1(4): 11121.

Yulyatin,A. danA. Diratmaja. 2015. Pengaruh Ukuran Benih Kedelai terhadap Kualitas Benih. Journal Agros. 17 (2) : 166-172. 